\title{
Concrete Governmentality: Shelters and the Transformations of Preparedness
}

Joe Deville, Michael Guggenheim and Zuzana Hrdličková

Keywords: Shelters, Materiality, Risk, Nuclear War, Preparedness

\begin{abstract}
This article analyses how shelters act as a form of concrete governmentality. Shelters, like other forms of preparedness, are political acts in the absence of a disaster. They are materializations and visualizations of risk calculations. Shelters as a type of concrete governmentality pose the question of how to build something that lasts and resists, and remains relevant both when the object that is being resisted keeps changing and when the very act of building intervenes so publically in the life of the restless surrounding population. Comparing shelters in India, Switzerland and the UK, we highlight three transformations of preparedness that shelters trigger. First we analyse how shelters compose preparedness by changing the relationship between the state and its citizens. Rather than simply limiting risk or introducing "safety", the building of shelters poses questions about who needs protection and why and, as we will show, this can generate controversy. Second, we analyse how shelters decompose preparedness by falling out of use. Third, we focus on struggles to recompose preparedness: Changing ideas about disasters thus lead to shelters being suddenly out of place, or needing to adapt.
\end{abstract}

\section{Introduction}

Consider this; there are three countries that each protects some of their people from harm with concrete structures capable of preserving life in extreme physical circumstances. If these concrete shelters could talk, they might tell us stories: stories about what sets them apart from others, about the people they are meant to house, and about the experts and governments that surround them. Perhaps it might go a bit like this:

When encountering the other shelters in our trilogy, shelters in country A might be tempted to adopt a certain swagger. These are a community of shelters whose population has grown rapidly in the last half century, heavily supported by their government, to the extent that they now sit embedded in the basements of every relatively new block of flats. "We can protect an entire population!", they declare. But push a little and you begin to find a niggling sense of self doubt. The disaster that they depended on for so long, a disaster they assumed would never go away, seems to be fading from view. And there is another problem: there have been persistent whispers of a need for these shelters to adapt to new kinds of disasters. But this is no easy task. These shelters feel themselves old, solid, concrete, and inflexible. Then: a ray of hope! After it seemed that its human population was about to stop the proliferation of shelters, a single disaster far away has shown some particularly influential members of this 
human mass that these shelters might, in fact, have a place in their society. The shelters can, for now at least, breathe a little easier.

Shelters in country B might be briefly taken aback by the lengthy experience and sheer scale of the community of shelters in country A; by comparison, this group of shelters is younger and can protect smaller proportion of the population. This hesitation is only fleeting. "Look", they say, "we, at least, are relevant!". They go on: "For thousands of years our country has been whipped by disasters. Now at last, we can protect people from them. Yes, perhaps we were a little late on the scene, but now we are here, we are needed!". As seeming proof of this there are plans for their community to be expanded. And, what's more, they are being made to be flexible. They have no need to worry about the fate of one single type of disaster, seeing as they are made to be able to adapt. Once again though, probe a little, and things are not so rosy: these shelters should be ready for disaster, but many now stand dilapidated, or are used for purposes which limit their ability to protect people if, and when, a disaster should strike.

The shelters in country $\mathrm{C}$ crumble away silently, listening to the argument between the other two. These are a diverse and often ragged assembly of shelters built, in very different ways and to very different standards, by the rulers of their country and by some of their population. They know that they are now on the way out, with a decline that started many years ago. A few of their number, designed to house the most influential people in the land, are struggling on, true to their original purpose. A few survive as tourist attractions. A few more sit in people's homes and gardens and are used as wine cellars. But, although low in number, they feel as if they know something the other two don't: that shelters may not be about offering material protection at all. But instead about human power and about human protest, where what is important about building a shelter is the act itself and the ability of this act to demonstrate either protection or, in fact, its almost total absence.

What these stories begin to show, and what we will explore further is that the relationships between 'risk', material 'protection' and the uses of concrete shelters is not a given. Shelters are not simply responses to risks. Rather shelters produce, react to and transform risks and preparedness. Their material presence poses questions about the plausibility of a particular risk, as well as the shelters offering themselves up to be read as a visual representation of what constitutes an acceptable level of survival and for whom. Rather than unravelling genealogies of preparedness we focus on how shelters transform preparedness.

We analyse three types of transformation. First, we focus on how shelters compose preparedness. That is, on how the building of shelters concretises the idea of state-led preparedness, in turn changing the relationship between disasters, citizens and the state. Rather than simply limiting risk or introducing "safety", the building of shelters poses questions about who needs protection and why and, as we will show, this can generate controversy. 
Second, we focus on how shelters decompose preparedness. ${ }^{i}$ That is, on changes in the shelter buildings themselves, and in particular their falling out of use. Shelters represent a particular form of preparedness intended to work through sheer materiality: the more concrete, the safer. However, as we will see, shelters become unusable when they lack support from the population or adopt other uses. Some are even built so frailly as to be proof of failed government policies.

Third, we focus on struggles to recompose preparedness. Shelters are designed according to the particular kinds of forecasting and disaster expertise of their time (and, indeed, place). Expertise evolves and changes, whereas shelters, as concrete, obdurate structures remain more or less the same. Changing ideas about disasters thus lead to shelters being suddenly out of place, or needing to adapt. We observe the different fates of shelters in the face of such changes in expertise by looking at the examples of shelters in Switzerland, India and the UK.

\section{Concretising Preparedness}

One of the main insights of disaster research is that disasters highlight the political constitution of reality. They show the way in which choices are made to do certain things one way and not another (see, for instance: Law 2003; Perrow 1984; Vaughan 1996, 2004).

Already in the 1930s Lowell Carr pointed out that disasters should be understood as a special case of social change (Carr 1932). It was the unique empirical situation surrounding the disaster that attracted him, for insights could be gained about society in general. Disasters were less important as a specific type of field for research and more for their unique, and total qualities, which made it possible to observe social change in action.

One obvious way in which disasters change society is that they have effects not only after they occur, but also before, or in what Carr called the prodromal period of disaster (Carr 1932: 210-211, see also the introduction to this volume by Guggenheim). Research has shown that there are a variety of preparedness practices which operate according to different logics (Lakoff and Collier 2010; Anderson 2011). These range from the deployment of what Collier and Lakoff call archival statistical knowledge (Collier 2008: 227-231), as for example in the form of insurance (Ericson and Doyle 2004), to training and exercises (Anderson and Adey 2011; Davis 2007), to planning documents (Clarke 1999), to the complex set of preparedness discourses discussed in the chapter by Weszkalnys (this volume). For us, what is crucial about preparedness is the relationship between these practices and disaster, as a more or less present object. We are not interested in different kinds of preparedness and their historicity, but in analysing how one particular concrete form, the permanent concrete shelter, ${ }^{\text {ii }}$ produces different kinds of social change. Importantly, this social change, produced through and by the shelter, can take place in the very absence of disaster - this very absence, indeed, is a material effect of its own. In disaster preparedness, then, the disaster can often become an absent transformer and it becomes obvious that preparedness itself enacts particular kinds of social change, independently of the presence of 
the disaster itself. Assessing whether or not disasters are 'triggers' for preparedness, and why, becomes an empirical question.

Carr was also farsighted in his understanding of disasters as perfect exemplars of the need for a more materially sensitive sociology. Carr critiqued culturalist accounts by showing the way that the natural world could not be straightforwardly tamed - and in fact had direct influences on the course of society (Carr 1932: 209). But more than that, the 'natural', non-human world was, for Carr, transformative. He followed disaster's social effects, ranging from the redesign of bulkheads after the Titanic disaster, to the sudden appearance of female conductors on streetcars after the major munitions explosion disaster in Halifax, Canada. Disasters, as Carr came to see it, co-produced the socio-material.

In disaster preparedness, and particularly in the case of shelters, this formulation is especially relevant. Shelters are concretised forms of preparedness produced by absent disasters. It is their very concrete existence, being made to withstand the worst kind of impact, be it from nuclear warheads or cyclones, which produces a lasting effect. They are not only material, but they are made of a material that is the very epitome of materiality: concrete, and as thick and durable as possible (Forty 2012; Slaton 2001). If technology is society made durable, this is one of the ultimate durable technologies. More than any other object or building type, the function and use of shelters is a direct effect of their sheer materiality. Unlike banks or churches, the successful functioning of shelters is not largely an outcome of sophisticated technological features or interior layout, but rather the sheer thickness of their walls and the rigidity of their design. We refer to this as concrete governmentality, building on Foucault's terminology. This refers to the ways in which the particularly durable, supposedly permanent aspect of concrete as a material through which to build protection, comes to both epitomise and shape relations between the state and the population. In concrete governmentality, governmental institutions use concrete structures to, quite literally, build up their conceptualisations of risk and the role of government in protecting civilians in the belief that the material properties of concrete can offer solutions to particular preparedness problems. While we focus on shelters, this could include a range of protective measures from levees, to embankments, to housing.

The sheer materiality of concrete also has particular effects where there is no disaster. Shelters remain present, even if the disasters for which they were originally built have ceased to be a threat or fashions of expertise have changed. This durability can have effects on reshufflings of the relationship between the state and the population. Preparedness is nowadays mostly a state led practice. ${ }^{\text {iii }}$ It is the state, acting through its standardisation mechanisms and organisations of civil defence and protection, that organises preparedness. This includes building shelters. However, precisely because of their durability, shelters can turn against their builders, while also standing as spaces which the public can use and adapt in various ways. As such, the population and the shelters shape preparedness as much as the state does, with the material as a specific mode through which the social is assembled, thus acquiring political capacity and actively shaping the course of political action (Marres and Lezaun 2011). 


\section{Composing Preparedness}

What is a shelter? How might it compose preparedness? Introducing three shelter programmes in different countries, we start by looking at how concretised forms of protection come to shape relationships between the state and the population. We begin in Switzerland and India, to show how certain kinds of disasters are transformed through shelter building programmes, in turn changing the relationship between the state and the population. In both of these cases we can observe how, through the introduction of new, standardised sets of buildings, the state extends its reach by claiming responsibility for its citizens in relation to specific disasters. ${ }^{\text {iv }}$ In the case of India, the concrete governmentality represented by shelters protects parts of the population considered to be vulnerable to disaster, because of their geographic location and housing conditions. In Switzerland, by contrast, we can observe an attempt to compose a total form of protection. The population is understood as homogeneous, with a shelter space built for each and every individual. We then turn to the UK, where we can observe quite the opposite. Here, a small minority of concerned citizens attempt to challenge the state preparedness provision, through their own material practices, by themselves taking on responsibility for shelter building. Their aim is to use the shelter as something akin to concrete 'proof devices', as a way of demonstrating the very absence of state protection in the face of seemingly imminent and total disaster.

India frequently suffers from devastating cyclones, ${ }^{\mathrm{v}}$ with the east coast and parts of the west coast being extremely vulnerable (NDMA 2008: 1-9). The level of vulnerability varies and some locations are more likely to be worse affected than others because of their latitude as well as topography. ${ }^{\mathrm{vi}}$ Until the 1970 s, cyclone disasters were understood by the Indian state as events to be responded to: their role was to provide care to victims after a disaster, potentially in collaboration with third parties. In this sense, in the preparatory or 'prodromal' phase, these disasters were rather undermaterialised. What materialisation there was - largely in the form of organisational responses - occurred only once the disaster had already happened.

From the late 1970s, this began to change, in particular in the aftermath of the 1977 Andhra Pradesh cyclone. With extensive support from the Red Cross, over 200 new shelters were built in a period from 1978 to 1982 (McKerrow 2010). This was followed by a second building programme in the aftermath of a sequence of disasters occurring in the late 1990s and early 2000s. ${ }^{\text {vii }}$ On the back of a sudden influx of funding and due to a new government disaster management framework ${ }^{\text {viii }}$ a new, "second generation" of Indian shelters began to appear (Interviews in South India, July 2012; and NDMA (2008: 10-15)). ${ }^{\text {ix }}$

These two periods of shelter construction should not be simply understood as having been 'triggered' by the disasters that preceded them. Rather, what we see in both periods is a shift in both the temporality and materialisation of disaster, with a general shift in emphasis 
towards preparedness, and, in particular towards materialised preparedness through the built environment. Furthermore, in this process, as relevant as the disaster 'itself', are the changing forms of expertise and sources of funding available for preparedness activities, with the construction of shelters increasingly involving not only (local) government actors but also humanitarian/development organisations, along with community-based and other nongovernmental organizations. Binding much of this diverse input of expertise together is a confidence in state-led forms of standardisation, with the designs for the shelters being produced by (or in cooperation with) the Public Works Department (Interviews in South India, July 2012). The result of this new alliance of expertise, control, funding, and practice, has been to transform disasters into manageable events, which can be affected by, in this case, concrete forms of action, prior to a future event.

Insert Figure X. Design of circular shelter - Public Works Department of Puducherry. ${ }^{\mathrm{X}}$

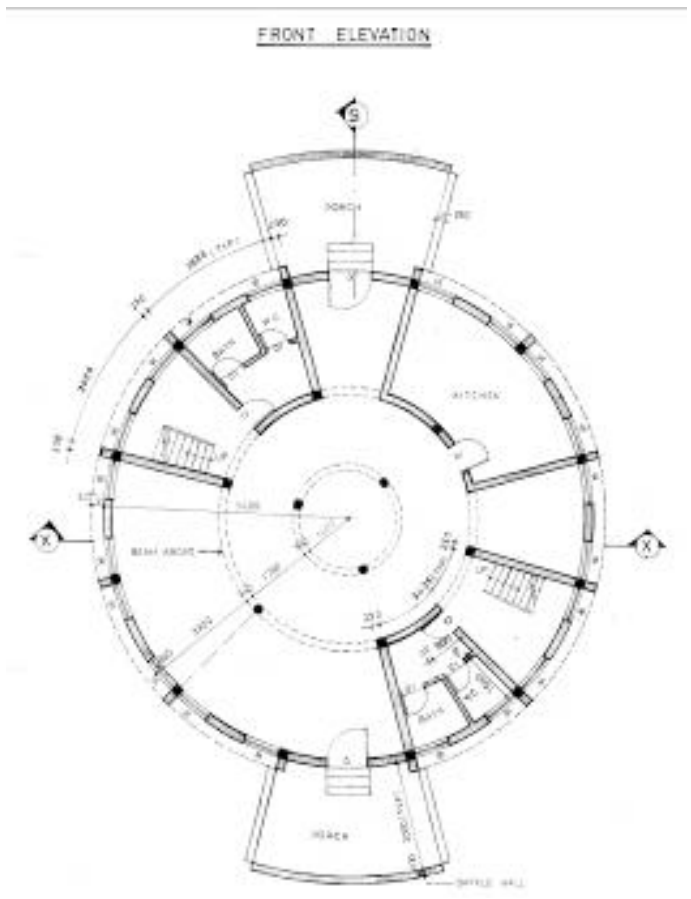

Insert Figure X. Photo of circular shelter in Vadapattinam. Photo by Z. Hrdličková, 20th July 2012 


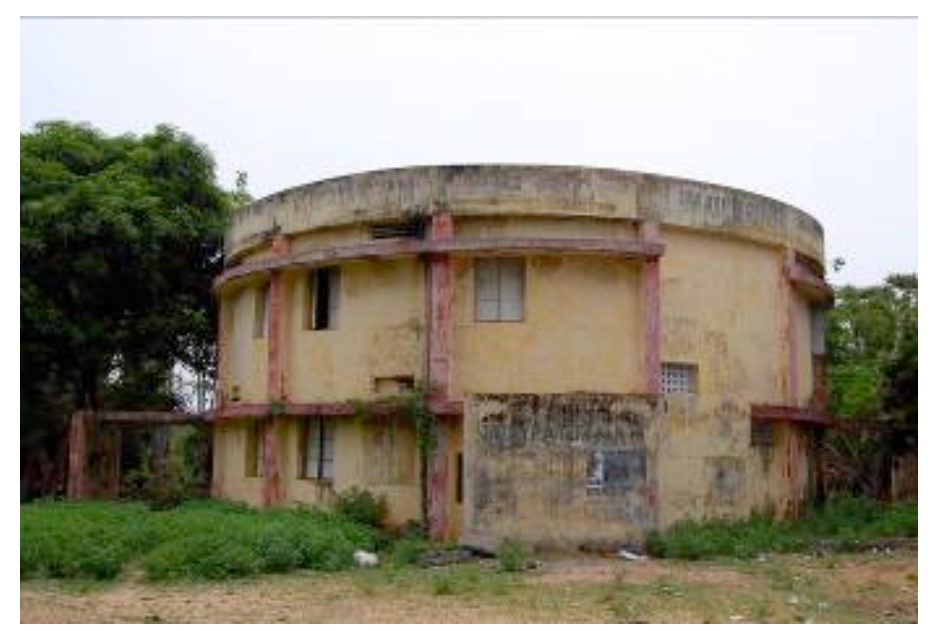

The disaster to which the Swiss shelter was designed to answer - possible nuclear attack was quite different to India's cyclones. This is not simply because of the quite different place of human agency in constituting the two threats, or the different way they distribute harm. It is also because, like virtually every other country in the Cold War that was seeking to deal with the danger posed by the proliferation of nuclear weapons, Switzerland was faced by a threat of potentially catastrophic proportions of which it had had no direct experience. This is a small but important point: one needs to be cautious about drawing causal inferences between the presence of disaster and the presence of preparedness measures. Discussions within the Swiss government about the need for a comprehensive defensive response to the threat of nuclear proliferation started soon after the Second World War ${ }^{\mathrm{xi}}$. However, it wasn't until the early 1970s that this initial ambition began to be pursued in earnest, with a promise made by the Swiss government to its people in their entirety: that if there was a nuclear attack, there would ultimately be a space in a nuclear bunker for each and every Swiss inhabitant (Schweizerischer Bundesrat 1979: 19) This commitment was backed with significant levels of funding, it was legally enshrined and its delivery was rigorously monitored (see: Schweizerischer Bundesrat 1979: 20). Fast forward around half a century, and the results are startling: there are now enough spaces in these bunkers, designed to withstand a nuclear assault, for just under $100 \%$ of the population. The backbone of this provision is around 300,000 private shelters - on top of 5000 larger public facilities - built into many Swiss homes and apartment blocks (Eidgenössisches Departement für Verteidigung, Bevölkerungsschutz und Sport 2012: 59).

\section{INSERT PICTURES - JD2}




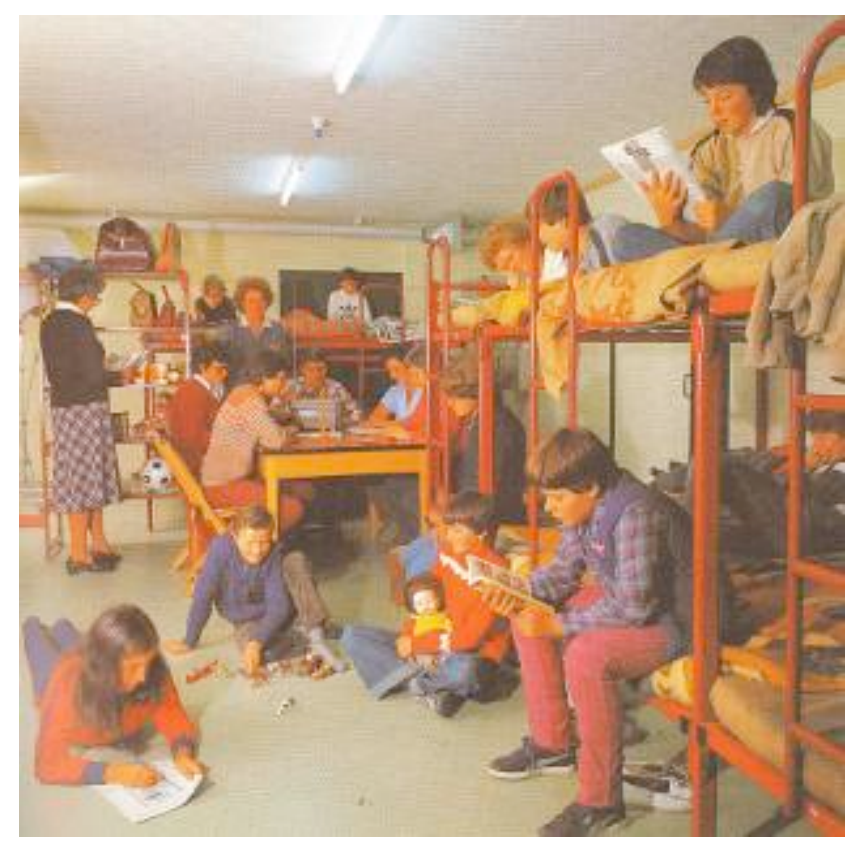

Their differences notwithstanding, disaster preparedness epitomised by shelters in both India and Switzerland thus involves deeper engagements between the state and the population, mediated and shaped through concrete, that is through the state sanctioned building of structures for the protection of the population. This is partly because the governing structures of both countries play a central role in maintaining a degree of control over the shelter programmes, with both envisioning that their duty is to ensure the survival of their civilian populations. Shelters also concretise a confidence in the value of dedicated, technical, material solutions to disaster, whether the disaster is apparently natural or man-made in origin [see: Berger Ziauddin, 2010]. The absent disaster, whether nuclear explosion or a cyclone expected to arrive sometime in the near future, is transformed into an entity that, with the right application of technique, as concretised into a built material response, can be if not eliminated then at least managed. In both cases, the shelters compose preparedness anew, uniting the state and the population in the imagined, or soon to be present disaster. As an instance of concrete governmentality, the shelter folds government and population together.

In the case of the UK however, we can observe how shelters composed preparedness not through concrete presence, but absence. For, after the Second World War, the UK made virtually no attempt to provide the population themselves with protection in the form of nuclear shelters. This was a decision taken mostly for financial reasons as early as the $1950 \mathrm{~s}$ (Smith 2010) and it placed UK civil defence in an uncomfortable position: it was tasked with warning the population about an imminent nuclear threat while at the same time being unable to offer any significant material protection. Indeed, the civil defence establishment repeatedly complained about this situation, to no avail. The culmination of the lack of support, in 1968, was the total abolition of civil defence as an autonomous organisation dedicated to disaster response (Grant 2010; Stafford 2011). The particularly stark contrast with Switzerland points to the inevitably political logic of disaster preparedness: although both nations were faced with very similar threats, the UK did not, in anything like a serious or sustained way, act to protect the population through the building of shelters. 
The government did build some shelters, but their principle effect was largely unrelated to their specific protective features. More important than how they might protect a few additional people was what the shelters revealed about the asymmetries of protection. As revealed first by "the spies for peace" activists in 1963 (Anon 2007), and then, more famously in 1982, by Duncan Campbell in "War Plan UK. The Truth About Civil Defence in Britain" (Campbell 1982: 180-224), although the government denied the need for shelters for the population, it actually had built a number of shelters for its top civil servants. Indeed not only had it built these exclusive shelters, but a whole infrastructure designed to keep the country running during a nuclear war and in its aftermath. At least some of these buildings were constructed to the highest standards and were coupled to the most complete possible infrastructure. Ultimately, this amounted to transforming preparedness into an object involving multiple, increasingly visible asymmetries. The UK ended up as a country in which the state made an explicit decision that the government and parts of the administration was worth preserving even if it meant the ultimate absence of a population and an inhabitable territory.

The shelters that were built by the state thus had a double effect: the first was to build in a split in protection. The British shelters would have protected the government and some civil servants, who, in a very technical sense, would have been able to keep the country running, even in the perverse case of an extinct population. This fragmented the idea, so frequently invoked by the government in its public proclamations, of a unified nation, threatened as a whole by nuclear bombs (a similar notion to that routinely circulated in Switzerland). This particular vision and valuation of society became architecturally split in two by the concrete form of preparedness designed for the imagined bomb. If the disaster were to ever arrive, its effect would be to render visible, in the most brutal and extreme manner, cleavages between population and government.

This split could be disguised as long as the government shelters were not known to the public. But the fact that this kind of reasoning was eventually made public meant that the shelters became very visible and very real for the British population. The second effect was thus for the shelters to become demonstrations of the civil defence bureaucracy's non-belief in either its own assessment of the unlikelihood of a nuclear attack (otherwise why was it building shelters for itself), or, if an attack did come, in the adequacy of the kinds of improvised solutions recommended by the government to the British population (to be explored shortly). In the case of the UK the controversies around the concretisation of preparedness very much obliterate the issue of the disaster itself and instead highlight the precarious relationship between the government and the population. The disaster is not thus simply an external force against which a defence is built.

As we will see in the next section, the full story of the composition of preparedness in the UK cannot be told only with reference to state-built shelters. Yet before we address this, it is important to illustrate how the transformation of preparedness that shelters effect, despite being so apparently obdurate, occurs also through their ongoing, processual interactions with 
other events, not necessarily limited to disasters. In other words, temporality matters, precisely because shelters are built before disasters happen.

\section{Decomposing preparedness}

Once shelters are built, they are testament to a particular idea of government preparedness. However, other constituencies apart from the government both build and use shelters for various reasons and in various ways, which are very often at odds with the ideas of preparedness originally informing their construction. This is not simply a story of the power of users to adapt technology to suit their needs (Oudshoorn and Pinch 2003). Rather, what is at stake is the very functioning of shelters for their designed purpose. The problem here is twofold: First, because shelters are extremely obdurate structures, they exist for a very long time, but, since disasters are infrequent, are rarely used. They may thus either outlive the disasters for which they were built, as we will see in the case of Switzerland, or become used for other things, to the point that they become unusable in case of a disaster. This we refer to as the 'decomposition' of shelters. Second, since the promise of a particular shelter is a function of both a disaster forecast and calculations about how materials might combine to withstand a disaster, shelters can be simply unusable from the outset. In the UK, as we will show, a hobbyist scene emerged in which people started to build shelters themselves to counter the absence of government provision, but these shelters were very often more a political statement than a usable shelter. Here the very composition of shelters in one social domain threatens to decompose the shelters in another.

In Switzerland, with its seemingly universal, egalitarian promise of protection, one of the features of the security establishment's relationship with the public is a sense that the population were not as signed onto the whole Swiss civil protection concept, including its network of concrete shelters, as much as they should have been; as Berger Ziauddin (2012) has shown, apathy about — and disengagement with - the shelter amongst the Swiss population is a key a feature of its history. In the earlier Cold War days, there was a concern with a Swiss public that was understood as problematic by virtue of being 'uninformed'. The suggestion was that, if the public understood the issue presented by the nuclear threat as well as their protectors did, their attachment to Swiss civil protection measures would be stronger. But, in nearly the same breath, the establishment wondered if perhaps the problem was, in fact, that the proliferation of imagery of nuclear destruction in various forms of visual media meant that the population was over-exaggerating the nuclear threat. There was talk within the Swiss civil protection establishment of a prevailing 'fatalism' which was impeding their work - a sense that, given the destructive power of nuclear weapons in the event of a third world war, its protective measures might be useless (Y. Meier 2007: 136-137). This central problematic was summed up, in a 1969 article, which acknowledged that it was "exceptionally difficult, in both an understandable and convincing manner to, on one hand, acknowledge the ultimate possibility of total destruction and, on the other, show that this is only one variant, and a very unlikely one, amongst all the possible dangers" (Y. Meier 2007: 137; citing Rimathé 1969: 43). ${ }^{\text {ii }}$ In other words, the shelter, on its own, could not solve the 
problem of protection for the Swiss establishment. To read accounts from the time is to be struck by the sense of frustration, perhaps even sometimes bafflement, at this fact.

Later, in the $1980 \mathrm{~s}$, alongside a marked increase in media attention to rising numbers of conscientious objections to civil protection (Zivilschutzverweigerung) (M. Meier 2007: 186) ${ }^{\mathrm{xiii}}$, the increasingly powerful campaign for nuclear disarmament shifted the problem: this movement questioned the very definition of the concrete shelter as an entity that was primarily concerned with 'protection' (see also Berger Ziauddin 2012).. As most clearly expressed in a collection of critical essays published in the late $1980 \mathrm{~s}$, the shelter was described, in effect, as an anti-political device (Barry 2002; Ferguson 1994) that impeded broader debates about the very existence of nuclear weapons. It was therefore, effectively, contributing to making daily life less safe. The Swiss population, it was argued, imagining themselves safe underground as the nuclear bomb hit, could avoid engaging with, taking responsibility for, and challenging the global threat to humanity (Figure X, see also (Albrecht et al. 1988; M. Meier 2007: 175-186)).

Figure $\mathrm{X}$

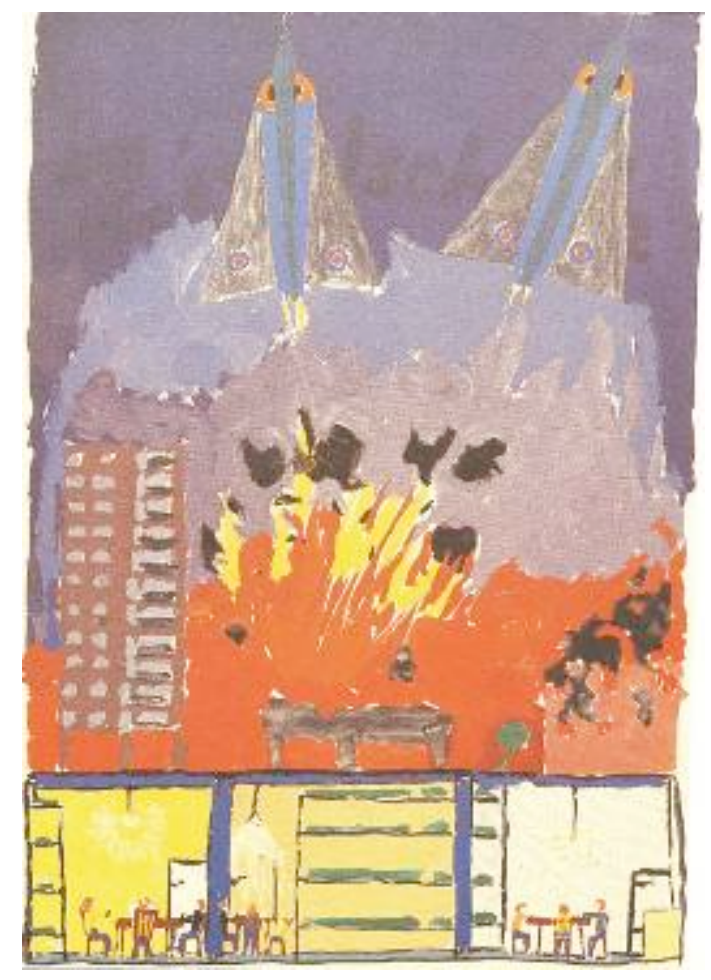

Once again, the promise of protection materialised in the shelter itself is not enough: the Swiss population are a body of people that needs to be actively attached to the Swiss civil protection programme and to its network of bunkers. The problem in the 1980s was that not only was the security establishment encountering a population that was ambivalent about shelters, it was now encountering, in certain quarters, a population who were themselves trying to actively redefine the shelter: to themselves attach to its concrete fabric the idea that shelters might generate more dangers than they alleviated. The original promise of the 
shelters thus begins to decompose, as the shelters generate, amongst the population themselves, a very different way of doing and orienting the political.

Decomposition can also occur through practice. In India, for example, when cyclones have hit, these shelters have sometimes remained only partially employed. A local engineer told us that, during one of the larger cyclones of recent years, hurricane Thane, the new shelter in Veerampattinam, Puducherry, was used by around 10 families. Although this could still be a sizeable number of people, there is no sense that the facility was used to anywhere near its capacity, despite the fact that the shelter is likely the safest building in the village. This matches accounts about the historical use of some of the older shelters. One reason is that other concrete or brick buildings - labelled "pukka" - are perceived as equally safe and so are also used in disasters (churches, temples, schools and new houses). Another is that many residents are reluctant to leave their homes for fear of looters, especially if it is also made of brick or other resistant materials, which are likely to keep them safe in the face of moderate disaster. This points to a tension within the promise of protection concretised in these shelters in South India: they promise only to protect life, not livelihood. Given that the financially more secure residents who are likelier to live in more resistant houses - as well as being residents who may perceive themselves as potentially at greater risk of looting given their status - this means that shelters, or other pukka buildings, are more likely to be used by the least well off. And the state knows it. As one of the senior officials implementing cyclone mitigation programme said, shelters are for "BPLs" - people 'below poverty line' (interviews in New Delhi March 2013). Some local inhabitants also prefer temples, in particular, over shelters, given that - to put their argument in our terms - they offer a metaphysical mode of protection that escapes, and cannot be contained by, processes of concretisation. Further, it should be noted that concrete and brick homes have proliferated since the building of the first generation of shelters, as incomes have grown. Whether or not these buildings are safer is not the point: particularly given the shelter's inability to protect livelihood (which staying in a pukka home might), it can no longer, by its mere presence, make an easy claim to offer the most effective form of protection. The promise of sheltering, by becoming distributed, has become decoupled both from one specific building type and from the strength of concrete.

Insert Figure X. Design of second generation of multi-disaster resistant multi-purpose cyclone shelters, also called community halls, Public Works Department, Puducherry, obtained on 19th July 2012.

[Awaiting image]

Insert Figure X. New use of old shelter for Chennai University, ECR, Tamilnadu photography: Z. Hrdličková 20th July 2012. 


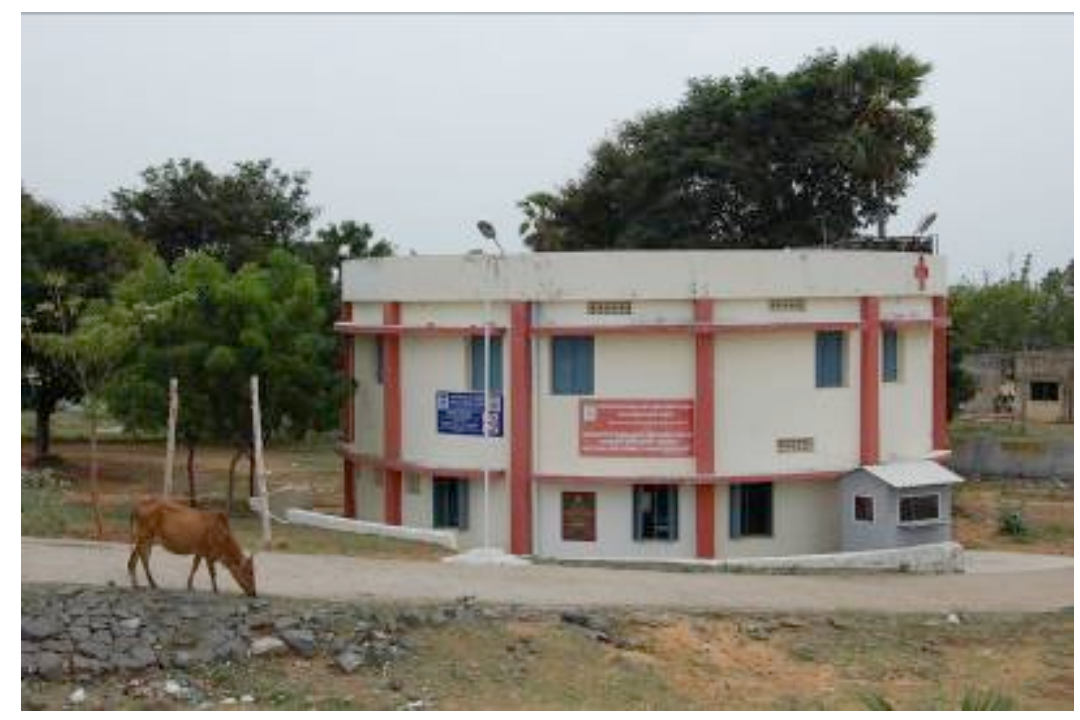

There is another problem for the Indian shelter, centring on its frequent acquisition of novel uses. Some are used as schools (Lavanya 2011) and crèches (McKerrow 2010). One we have seen was transformed into a police station. Another is used by the Chennai University as an administrative building. Some shelters have become hang outs for unwelcome alternative uses - "anti-social behaviour", as one interviewee put it. Although not of this kind, alternative use was envisaged in the design of the older shelters. For a little recognised fact is that, as shown in the original architect's model, these shelters were originally intended to serve, first and foremost, as community centres. The explanation popular among contemporary disaster management practitioners, saying that shelters from the 1980s failed because they were not owned by the community, does not therefore wholly stand up. The problems is rather what constitutes an acceptable 'community' and, as we will see, how, on its way down from the architect's table through the hands of organisations and local authorities, the very act of encouraging alternative use can begin to decompose the shelter's intended purpose.

Insert Figure X. Model of the first generation circular shelter called "Community Centre for Cyclone Affected Areas”, photography: Z. Hrdličková $16^{\text {th }}$ July 2012 


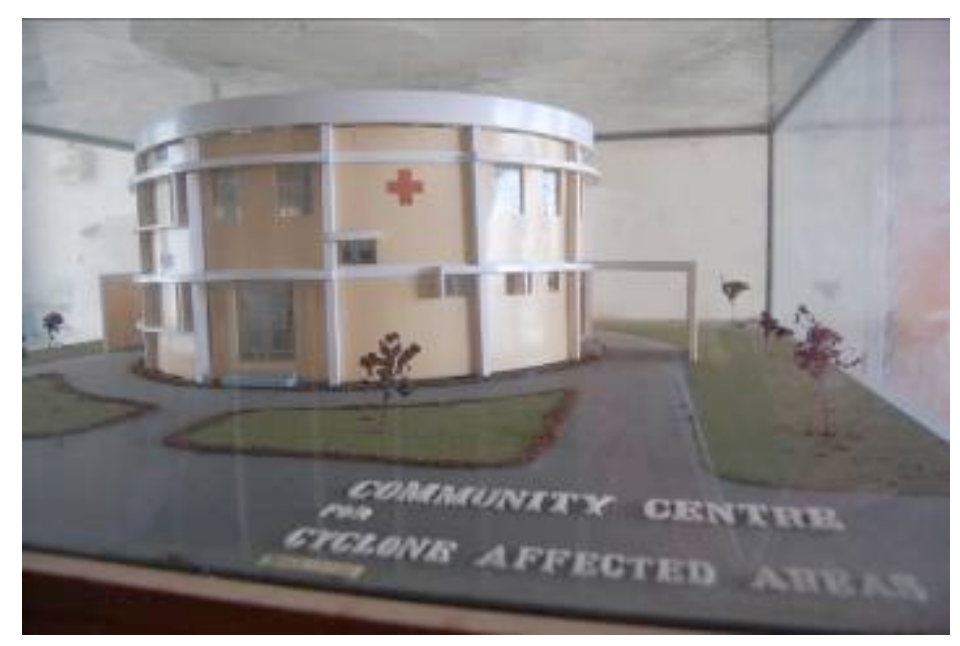


Insert Figure X. Multi-purpose shelter/ community hall in Veerampattinam outside Puducherry, photography: Z. Hrdličková 18th July 2012

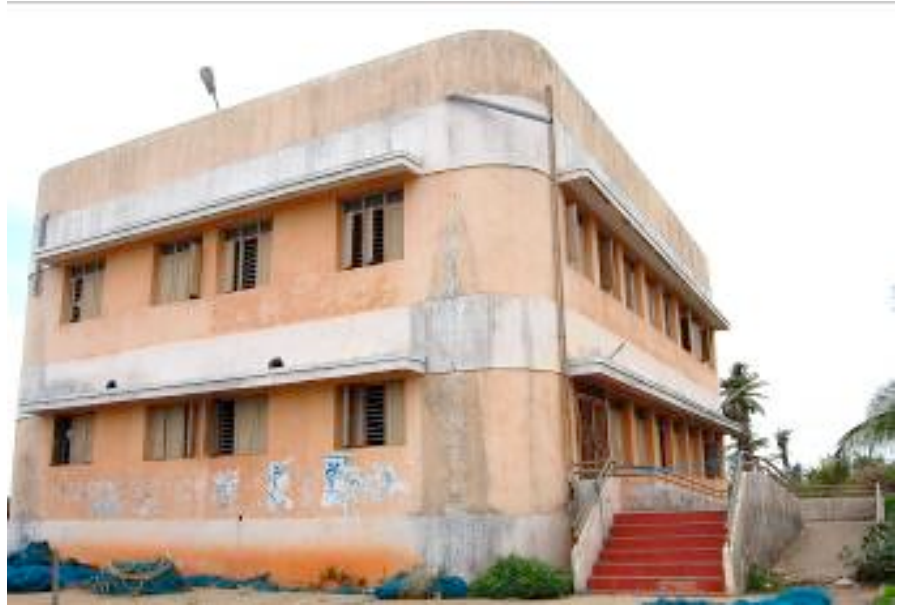

The promise of protection and of multi-use is replicated in the newer centres: as their architect told us, it is key that the community use these buildings for other purposes during the year, otherwise they will become obsolete. So, for example, the first floor is designed as a marriage hall, with separate rooms for the bride and bride-groom. This mirrors a stipulation meant to accompany the original shelters: that they should not become permanent offices, because of the hardware and general clutter that comes with such use. Further, in line with the participatory mantra prevalent in today's governance, the 'Design Recommendations for the Construction of Cyclone Shelters' clearly state that the local community should be involved in the architectural design of the shelter (Ministry of Home Affairs 2005: 9). As so often, however, the precise role of community participation remains unclear. In the more contemporary shelters, it is the local authorities that provide the specifications - shelter capacity required, for example, and the topography of the area - and based on this data, the architects of the individual states produce a design. So, as before, questions arise about the limits of community. Is a local authority a part of the community or is it not? (Hastrup 2011: 79-97). Is it 'true participation' when the architects speak to local authorities rather than to community groups directly?

The problem, as explicitly recognised in the flexible, ideally inclusive design of the newer shelters, is that more permanent alternative uses prevent people from using the buildings for their original purpose - protection during tropical storms. This is the case in the shelter that is now a police station, for example. And, indeed, in the case of those shelters that have come to be associated with unwelcome social practices. Protection therefore proves to be an entity that can easily 'leak out' of these concrete shelters, if they are not surrounded by the right combination of everyday practices. ${ }^{\text {iv }}$ The concrete governmentality embodied by Indian storm shelters thus faces an uneasy task: how to make the population dwell in the shelter without endangering the very purpose they were built for. They have to be dwelled in without too much clutter in order to serve as shelters. 
The Swiss shelter shares some of these problems of decomposition with its Indian cousin. Until 2004, owners of individual houses and residential blocks in Switzerland had to ensure that their shelters could be clear and ready for use, in the event of a nuclear attack, within 24 hours. This meant that they could be used as storage places, much in the same way as other cellar spaces, but that no major alterations should be made, or devices installed that were permanent, or semi-permanent. The abolition of this requirement - with the argument that as the risk of a nuclear attack had decreased the likely forewarning time had increased - has meant that, in particular in the larger private shelters, some have been converted to other uses - into temperature controlled wine cellars or saunas, for example. ${ }^{\mathrm{xv}}$ Meanwhile public shelters, controlled by municipalities are, on occasion, rented out - for example, to host musical events. This has meant either the removal and storage of key machinery (filters, for example), or building work that has compromised the integrity of the shelter structure. The conversion back into a shelter thus becomes contingent on the restoration of shelter status: a process, which could take weeks, or even months. In both the Indian and Swiss cases the promise of sheltering has to coexist successfully with a range of everyday uses. For the shelter to be able to not only withstand a disaster, but also successfully house people in a disaster, it often has to withstand competing claims to alternative uses that emerge as the shelters interact with the environments and populations around them. Imagining, then, the participation of these now transformed, no-longer-quite-as-protective buildings in future disasters (whether cyclone or nuclear), we see how, in this now 'prodromal period' (to return to Carr's terms), the terrain upon which the disaster will intersect with both the shelter and their potential inhabitants, now likely to be housed elsewhere, is being shifted.

Decomposition does not have to refer solely to changes in the material fabric of a shelter. It can also occur when a competing protective materialisation threatens the credibility of another. This is what happened in the UK. Here it is the state shelters that decompose, but not through neglect or criticism, but through the construction (or composition) of a different way of doing sheltering.

In the UK, rather than providing protection against the nuclear threat in the form of state built shelters, the government assigned the responsibility for protection onto the population. If anyone was going to protect the British population from the threat of the bomb, it would have to be the British themselves. The government, in this scenario, became a producer and distributor of expertise - and not (with some exceptions, as we have already seen) a builder and concretiser of expertise.

Particularly emblematic of this are the experiments that the British government took place at a location called "Rose Cottage" during the 1950s and 60s. Rather than build and test actual shelters, engineers pursued knowledge that might be adapted to the everyday lives of British homeowners: using books against windows, for example, as a way of giving some protection from the effects of a nuclear blast. The problem was that the results of these experiments highlighted the very limits of expertise, divorced from concrete support, to be able to significantly alter the possibility of nuclear survival. It was revealed, for instance, that 27 inches worth of books against a window would be needed to provide any kind of protection 
(Smith 2010: 173), a figure not within reach of all but the most studious of British households.

Yet, far from deterred, successive British governments stuck to the task—of distributing, and not materialising, preparedness. The problem was that the limits of this soon became clear to much of the population. Particularly notorious were the "Protect and Survive" leaflets. Their advice, which was widely ridiculed, included building a "fall out room" for which "bricks, concrete or building blocks, timber, boxes of earth, sand, books, and furniture might all be used" (HMSO 1980). In these leaflets, and in British Cold War preparedness more generally, it is thus clearly not state led protection that is in play, but rather individualised bricolage.

It is of course not impossible for households to generate at least some measure of protection for themselves from a nuclear threat if the state chooses not to do it for them. This was the conclusion arrived at by a small group of people in the UK in the 1980s, whose work clustered around the journal "Practical Civil Defence". They believed not only that nuclear war was a real possibility, but also that it was survivable. Moreover, they believed it was worth funding the construction of nuclear proof shelters themselves.

Insert figure here: Shelter Advert from Practical Civil Defence, May/June 1983, p.32.

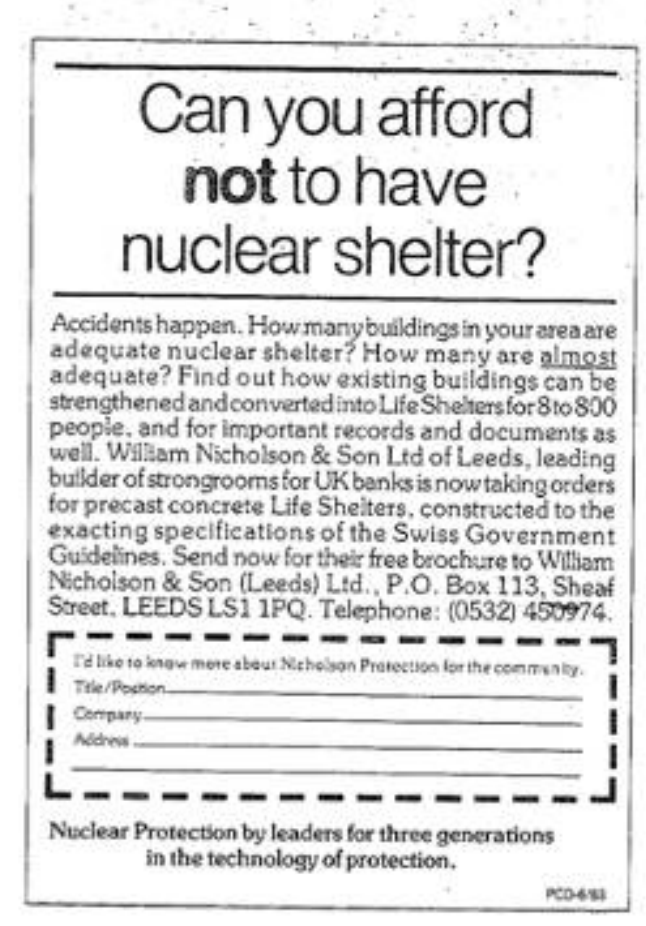

To do so, they had to solicit the service of firms to deliver items including entrance doors and air filters. The technicalities of protection and the question of what a shelter should look like thus became a matter of what information was available and choice. For instance, a guide to shelter design from 1983 mentioned "over two hundred companies selling prefabricated shelters, shelter designs and equipment" in the UK and included a list of suppliers. ${ }^{\text {xvi }}$ 
Here we find a peculiar twist: most of these suppliers were Swiss (Ormerod 1983: 17). And, when not, it is often adherence to "Swiss Government Guidelines" that is proclaimed as a key selling point. Swiss standards became the blueprint for the UK as, for shelter builders, this provided access to a form of standardisation. Sadly for British shelter builders, Swiss standards did not solve all their problems, for the shelter suppliers would generally only deliver parts of the home built shelter. The result was that both in their plans and in their construction, these shelters often did not approach the quality of Swiss shelters - in fact, many were rather makeshift. But this is not surprising. For, not only did the UK government step back from providing shelters, by itself proposing very makeshift forms of protection, it also had its own regulatory authority replaced by that of another state, Switzerland, but with no means to control it. Swiss shelter standards became hypothetical standards in the UK, but without any accompanying enforcement.

What kind of preparedness these building practices actually compose? A certain form of protective material bricolage, perhaps. But more important, we suggest, is that these localised, individual compositions each enact a decomposition of preparedness: a decomposition of the idea of the state as materially responsible for the survival of its population.

This can be illustrated with an example: one Graham Bate built a $13 \mathrm{ft}$ by $10 \mathrm{ft}$ concrete shelter equipped with a "radiation meter and a Swiss-designed system to filter out radioactivity" (Anon 1983b: 31). This 30-year-old civil engineer at the Yorkshire Water Authority built it under a six foot high mound of earth to protect him, his wife and their three children. His justification for building it: "Anything's better than the apathy evident in the UK about civil defence these days" (Anon 1983b: 31). 
Insert Figure X here: Bate_shelter, (Anon 1983b: 31).

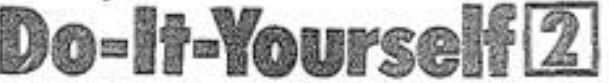 \\ SAFER THAN HOUSES:}
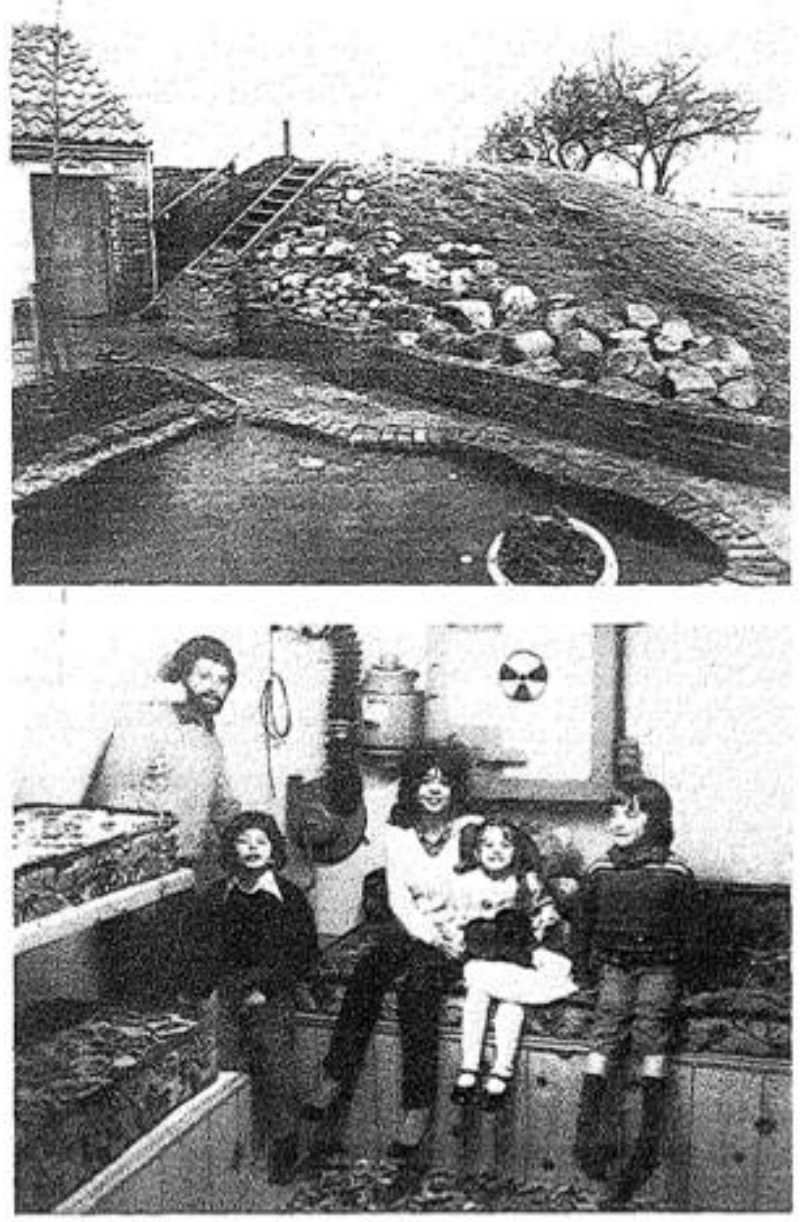

As Bate is well aware, it is thus not only the practical responsibility for shelter building that is shifted onto the population, it is also keeping alive the very issue of materialised protection for the population. While we do not know whether such shelters would have withstood a nuclear attack, we do know that they never had to. Their role was to prove that, indeed, the state did not provide material protection for all, or even acknowledge the importance of doing so. The construction of these shelters demonstrated that these builders, in contrast to their own government, and many other citizens, did believe in both the possibility of nuclear war and the value of preparing to survive it.

At the same time, doing protective, self-responsibilised protective politics meant overcoming apathy to show, through their activity and personal endeavour that "anything is better than nothing". This turned a technical problem - how to build a structure that can counter the effects of a nuclear attack - into a demonstration of an 'as if' mode of state-led politics. As captured in another article in Practical Civil Defence: "Whilst politicians and civil servants procrastinate over the cost of 'effective' civil defence measures men of 'iron will' and 
foresight are applying hard won engineering skills to the job of answering this nation's need" (Anon 1983c: 17). For these men (it seems they all were men), it did not matter so much whether their shelters provided adequate protection against a certain likelihood of attack. What mattered was proving that, even if buried in their garden, protection could be made concrete, even if it would never withstand the bomb.

\section{Struggles to recompose preparedness}

The last transformation we want to focus on are the struggles to recompose preparedness through shelters. As we have shown, shelters concretise particular ideas about preparedness. These relate in part to how the relationship between the state and the population is understood, but also to particular expertise about disasters. The idea, at its most simple, tends to be that the more expertise gets 'fed into' shelters, the better they will be able to withstand disaster. As we have seen, this expertise might range from the design of the shelter's protective features to ideas about how to ensure shelters are an ongoing success, by helping them fit cleanly into their surrounding populations. However, what often passes unrecognised is that it is not only unknown future disasters which the shelter might have to confront, but also unknown future changes in prevalent modes of expertise. It is in these moments that a shelter has to either recompose preparedness in such a way as to remain included, or face irrelevance.

The Indian cyclone shelters built in the late 1970s and early 1980s, the Swiss state led nuclear shelters, and the British hobbyist shelters can be seen as all standing for a mode of disaster expertise in which disasters are viewed as distinct entities, that need to be prepared for in distinct ways. However, this heterogeneous approach to disasters has increasingly become unfashionable and an approach highlighting the necessity of multi-hazard preparedness has been on steady rise since the 1980s and increasingly so since the 1990s. As Andrew Lakoff has documented (Lakoff 2007: $262 \mathrm{ff}$.), the roots can be found in the end of Cold War. The US preparations for nuclear attack had to shift away from threats posed by a 'stable enemy' and towards those from a 'nonspecific adversary' (Lakoff 2007: $263 \mathrm{ff}$.). Thus the all-hazards approach began to move towards its contemporary position as the world's preeminent mode of assessing disaster risk. The approach was firmly internationalised when the UN declared the International Decade for Natural Disaster Reduction in the 1990s, which targeted developing countries, and established that countries should strive for disaster preparedness through an all hazards approach rather than through a reactive response mode (Lechat 1990, Sharma 2000).

The second generation Indian shelters, mentioned earlier, can be seen as attempting to recompose a concrete form of preparedness in such a way that it follows this new mode of expertise. The new shelters are no longer formally branded as cyclone shelters only. They are instead envisaged as multi-disaster resistant structures, the specific design of which depends on the types of disasters the particular area is prone to. The shelters on the south-east Indian coast are therefore designed as earthquake-resistant structures that can also withstand strong 
winds and flooding, whether caused by cyclone, storm surge, or tsunami. In contrast with the highly distinctive circular shape of the first generation shelters, the newer models in South India have a more conventional, rectangular appearance. Although, on second inspection, they retain specifically disaster-resistant features, with rounded corners to enable them to better withstand wind power and other features ${ }^{x v i i}$ that make them resistant to other disasters, such as earthquakes or flooding. If these shelters had a message it might be that concreteness and flexibility are not inherently antithetical.

Yet how safe are even these new shelters from future changes in fashions of expertise? Despite their promise of flexibility, they cannot escape the central problem at the heart of all shelters: that particular modes of expertise become built into them. What happens, then, when buildings stay the same but the disaster changes? The UK, after all, did at one point have a huge shelter infrastructure, built in response to the Second World War air raids. In 1983, the journal Practical Civil Defence, the same community that built makeshift shelters, was so desperate in its quest for shelters that, in an article entitled "Dereliction?", it called upon its readers to participate in a "nationwide derelict shelter survey" (Anon 1983a: 25). Readers were invited to photograph these now seemingly irrelevant shelters and the journal would send the compiled documentation "to the Minister of State for Home Defence, at the Home Office" (Anon 1983a: 25). The idea was to rehabilitate a concretised form of preparedness from another age. This rehabilitation of course required an accompanying conceptual shift (a proto form of all hazards expertise, if you like): that a shelter ultimately need not necessarily be tied to one type of disaster, but could be adapted to different disasters, in which their reuse would happen "at a fraction of the cost of starting all over again" (Anon 1983a: 25).

This undertaking was unsuccessful, an outcome that might not have come as much of a surprise to the Practical Civil Defence community. Yet what they failed to recognise was that the fate of these forgotten shelters foreshadowed that of their own homemade shelters. After the waning of the Cold War, these too lost their obvious use. Additionally, from the late 1980s onwards, the UK slowly moved towards an all-hazards approach, as officially embraced in the 2004 Civil Contingencies Act (HMO 2004). With the apparent decrease in the nuclear threat, this implied there was no longer a need for the government to justify their (non) shelter building policy, nor were there any fringe groups calling for shelters. In 2010, a certain Mr Mike Thomas tried to sell his house including a nuclear proof shelter with, unavoidably, a "Swiss-made ventilation system" that he built in 1985 (Daily Mail Reporter 2010: no pages). Asked against which kind of disaster the shelter might now protect, $\mathrm{Mr}$ Thomas, answered: "It could still be used as a panic room if someone came burgling the house" (Daily Mail Reporter 2010: no pages). Mr Thomas struggles valiantly, by force of necessity, to recompose his own concrete form of preparedness as a private version of an all hazards approach, in which the state plays no role.

There are clear echoes here between the struggles of Mr Thomas and his shelter and the recent history of the Swiss shelter. In Switzerland, nuclear shelters are buildings similarly tied to one threat: the threat of military, nuclear attack. At the same time, the Swiss government has mirrored many others by seeking to take into account and prepare for a 
diverse range of dangers, assessed according to an evaluation of their risks and potential impact. In Swiss civil protection discourse you therefore see a move from a Cold War security stance, in which the bunker was placed at the absolute centre of civil protection strategy to the contemporary situation in which, despite much talk of risk analysis, and despite countless reports, there is never any justification made for shelters on the basis of a formalised risk calculation. ${ }^{\text {xviii }}$ These infrastructural, Cold War remnants still will not fit cleanly into a modern, risk based, ideally flexible - what in a 2010 report comes to be called ideally 'networked' - preparedness strategy (Schweizerischer Bundesrat 2010).

In the struggles to recompose preparedness there is one phenomena that helps shelters more than any other, and certainly more than any particular form of expertise: a disaster demonstrating their relevance. On the 9th March 2011, the Swiss parliament in Bern looked to be taking the first significant step towards ending the Swiss shelter programme, as they voted to abolish the requirement for new buildings to include a shelter. ${ }^{\text {xix }}$ However, on the 11th March, just under 6000 miles away from Bern, a huge earthquake struck Japan, damaging a reactor at the Fukushima nuclear power plant. In the weeks that followed, it became clear that this might become the most significant nuclear accident since Chernobyl. Influenced by this turn of events, the Swiss senate rejected the decision of the parallel chamber and on the 6th June the parliament reconsidered and reversed its original decision; ${ }^{\mathrm{xx}}$ the duty to include a bunker in new Swiss homes was maintained. The shelter had escaped its end by a hair's breadth (Anon 2011b, Anon a; Putzier 2011). Indeed, it is not an exaggeration to say that it is now Fukushima that is being concretised into the Swiss shelter as it struggles through its post-Cold War afterlife. A remote natural-human made disaster has, for now at least, given new life to this troublesome part of Switzerland's civil protection apparatus.

\section{Conclusion: The Concrete Transformations of Preparedness}

In our account we have spoken for shelters, taking something of a liberty seeing as it is likely that these obdurate structure would prefer to sit silently and solidly as they always do. They don't talk to each other, and keep their secrets, their promises and opportunities as well as their futility and unusability with them. In India, shelters might look over at their neighbours - houses - increasingly made of concrete too, and wonder how much longer it will take before all houses are built sturdily enough to resist cyclones and other disasters. Swiss shelters perhaps wonder, why they were built in the first place, when nobody uses them. Maybe shelters in the UK might consider what would have happened, if they would ever have needed to be used. Would those that protected the government have felt ashamed for the population dying around them? Would those that were built by hobbyists have even had time for embarrassment before they collapsed in the face of a nuclear blast, which they were inadequate to resist? Behind all this wondering is a shared question: why, despite all being 
built to save lives, do they all seem to embody a certain futility? That is, why had nobody thought better about their fate beforehand?

The answer, as we have shown throughout this article points to the particular qualities of concrete governmentality. The broad lesson of the story is that it is not simply disasters that transform the relationships between the governing and the governed, between the state and the population, so too do practices of preparedness. And they do so even in the absence of disasters. Disasters do not merely serve as excuses for the state, to justify acting in ways not possible under normal circumstances. Disasters are absent transformers: They produce the very problem of preparedness even if they never occur.

As forms of concrete governmentality, shelters are some of the most paradoxical and puzzling forms of preparedness: First, through their very material existence they materialize and compose, in public, particular relationships between the state and the population. They materially and visibly enact what are usually thought of as the unseen mechanisms of governmentality. In Switzerland they embody the population as a unity, while in India and the UK they fracture the population vis-à-vis the state. Second, shelters also decompose. Their very material existence can become a problem, for example when the need to keep cyclone shelters operational becomes an affordance for other practices that, in turn, makes them unusable. Lastly, disasters themselves, as products of the same forecasting techniques and expertise as shelters, may simply disappear. Concrete shelters, precisely because they are so durable, then need to recompose, and to find new forms of expertise and new disasters, which can justify their continuing role in processes of concrete governmentality. One particular form of expertise that has played this role in all of our cases, in various guises, is all hazards. In India it is by demanding that cyclone shelters should also withstand earthquakes and floods. In the UK, the all hazards ethos is deployed via private, improvised practices, while in Switzerland, the range of disasters is expanded with the help of an unexpected event: Fukushima.

Taken together, the problems that we have identified with preparatory shelter building is not a denunciation of concrete governmentality but rather an appraisal of the very concrete problem of preparedness: how to build something that lasts and resists, and remains relevant 
both when the object that is being resisted keeps changing and when the very act of building intervenes so publically in the life of the restless surrounding population.

\section{Acknowledgments:}

We gratefully acknowledge funding by an European Research Council starting grant (GA 263731 OD) that made research for this article possible. We would also like to thank the various interview partners. For critical comments we would like to thank the editors of the volume, the series editor Chris Shilling, the three external reviewers, as well as Silvia Berger Ziauddin, Aurora Fredriksen and Monika Krause.

\footnotetext{
${ }^{\mathrm{i}}$ For another take on processes of composition and decomposition, see Marres (2011).

ii Concrete shelters should not be confused with the humanitarian temporary or semi-permanent 'shelters' which are usually set up in the aftermath of a disaster.

iii One might argue that in the global South preparedness is nowadays mostly led by international institutions such as the World Bank and the UN agencies. However, these preparedness building projects emphasise active partnerships with state actors with the ultimate envisioned goal that the state would become the leader in preparedness building.

${ }^{\text {iv }}$ On the importance of standardization see Timmermans and Epstein 2010.

V "In the last 270 years, 21 of the 23 major cyclones (with a loss of about 10,000 lives or more) worldwide occurred over the area surrounding the Indian subcontinent (India and Bangladesh)" (NDMA 2008: xxiv).

${ }^{v i}$ Four states (Tamil Nadu, Andhra Pradesh, Orissa and West Bengal) and the Union Territory of Puducherry on the east coast and Gujarat state on the west coast are more vulnerable to hazards associated with cyclones (NDMA 2008: xxiv).

vii E.g. the 1999 Orissa Cyclone, the 2004 Indian Ocean tsunami

viii Based on Disaster Management Act (DMA) 2005, the mitigation of the impacts of disasters became a priority for the Indian state and led to the setting up of a new structure of organizations headed by the apex body National Disaster Management Authority (NDMA).

${ }^{\mathrm{ix}}$ Disasters that are unexpected and/or cause a great loss of life can generate a reaction of shock which can become translated into an influx of donations by the public, organizations and other states and the political will to respond.

${ }^{x}$ Obtained with permission of Mr. Gopalakrishna, PWD architect, 19th July 2012.

${ }^{x i}$ A nuclear deterrent was also actively pursued for a period, but ultimately rejected.

xii Our translation.

xiii This itself needs to be understood as growing out of and related to an ongoing leftist critique of Switzerland's Total Defence (Gesamtverteidigung) concept, centring of the power and influence of the Swiss military. This is a critique that persists, in altered form, today.

xiv The line is thin indeed. As Hastrup pointed out quoting the work of Ingold, if structures are to be relevant and serve their intended purpose, they have to be dwelled in (Hastrup 2011: 50) or as disaster management practitioners put it, they have to be owned by the community.

${ }^{\mathrm{xv}}$ Drawing on interview data with Swiss civil protection officers, 2013.
} 
${ }^{x v i}$ It is worth noting parallels with the contemporary situation in the U.S.A, where it is perfectly possible-if you can afford it - to pay a company to build a shelter to deliver what it promises will be "the ultimate protection for you, your family, and valuables". See http://disasterbunkers.com/plans-and-specs.php.

${ }^{x v i i}$ Use of materials like the RCC (reinforced concrete) frame, light weight pre-cast concrete blocks, corrosion resistant steel and with structural specifications to withstand specified wind velocity, storm surge (up to $7 \mathrm{~m}$ high), and earthquake load (Ministry of Home Affairs 2005: 13-14); the shorter side of the shelter to face the coast (Chandra 2005).

xviii See Hagmann and Cavelty (2012) for an overview of the rise of the risk register as a technology of disaster management, including an exploration of some of the difficulties that have surrounded the adoption of this technology in Switzerland.

xix The so-called Schutzraumbaupflicht

${ }^{\mathrm{xx}}$ By 94 votes to 74 . 


\title{
Bibliography
}

\author{
Albrecht, P., Gross, A., Hohler, A.E., Hug, P., Lauterburg, W., Schnyder, T., Stocker- \\ Meier, M., Stöcklin, J., Suchomski, J. and Tanner, J. 1988 Schutzraum Schweiz: mit dem \\ Zivilschutz zur Notstandsgesellschaft, Gümligen; Bonn: Zytglogge.
}

Anderson, B. 2011 'Preemption, Precaution, Preparedness: Anticipatory Action and Future Geographies', Progress in Human Geography 34(6): p.777-798.

Anderson, B. and Adey, P. 2011 'Affect and Security: Exercising Emergency in UK Civil Contingencies', Environment and Planning A.

Anon 2007 'Archived Report - Danger! Official Secret - RSG6 Pamphlet', 28DaysLater.co.uk Urban Exploration Forums. Available at:

http://www.28dayslater.co.uk/forums/showthread.php/9044-DANGER!-OFFICIALSECRET-RSG6-Pamphlet [Accessed October 5, 2012].

Anon 1983a 'Dereliction?', Practical Civil Defence (May-June): p.25.

Anon 1983b 'Do-It-Yourself. Safer Than Houses!', Practical Civil Defence (May-June): p.31. Anon 2011a 'Nun also doch wieder Schutzräume: Nationalrat vollzieht Kehrtwende bürgerliche Parteien schwenken um', NZZ Online. Available at:

http://www.nzz.ch/nachrichten/politik/schweiz/katastrophenschutz_nationalrat_schutzraeume _1.10838252.html [Accessed June 7, 2011].

Anon 2011b 'Ständerat hält an Schutzraum-Pflicht fest: Maurer warnt vor Ländern mit Atomwaffen', NZZ Online. Available at:

http://www.nzz.ch/nachrichten/politik/schweiz/staenderat_haelt_an_schutzraumpflicht_fest_1.10766938.html [Accessed May 31, 2011].

Anon 1983c 'The Men of Iron...', Practical Civil Defence (May-June): p.16-17.

Barry, A. 2002 'The Anti-Political Economy', Economy and Society 31(2): p.268-284.

Campbell, D. 1982 War Plan UK. The Truth About Civil Defence in Britain, London: Burnett.

Carr, L.J. 1932 'Disaster and the Sequence-Pattern Concept of Social Change', The American Journal of Sociology 38(2): p.207-218.

Chandra, G.R. 2005 'Revenue- Disaster Management - Finalization of Design Criteria and Model Design for Cyclone Shelters Under the National Cyclone Risk Mitigation Project (World Bank Assisted)',

Clarke, L. 1999 Mission Improbable: Using Fantasy Documents to Tame Disaster, Chicago: University of Chicago Press.

Collier, S. 2008 'Enacting Catastrophe: Preparedness, Insurance, Budgetary Rationalization', Economy and Society 37(2): p.224-250.

Daily Mail Reporter 2010 'For Sale: Four Bedroom Luxury Home, Sea Views... and Underground Bunker Able to Withstand Nuclear Blast', Mail Online. Available at: http://www.dailymail.co.uk/news/article-1322143/For-sale-Four-bedroom-luxury-home-underground-bunker-able-withstand-NUCLEAR-blast.html [Accessed August 6, 2012]. Davis, T.C. 2007 Stages of Emergency. Cold War Nuclear Civil Defence, Duke University 
Press.

Eidgenössisches Departement für Verteidigung, Bevölkerungsschutz und Sport 2012 Strategie Bevölkerungsschutz und Zivilschutz 2015+. Bericht des Bundesrates.,

Ericson, R.V. and Doyle, A. 2004 'Catastrophe Risk, Insurance and Terrorism', Economy and Society 33(2): p.135-173.

Ferguson, J. 1994 The Anti-Politics Machine: "Development," Depoliticization, and Bureaucratic Power in Lesotho, Minneapolis: University of Minnesota Press.

Forty, A. 2012 Concrete and culture: a material history, London: Reaktion.

Grant, M. 2010 After the Bomb: Civil Defence and Nuclear War in Britain, 1945-68, Basingstoke: Palgrave Macmillan.

Hagmann, J. and Cavelty, M.D. 2012 'National Risk Registers: Security Scientism and the Propagation of Permanent Insecurity', Security Dialogue 43(1).

HMO 2004 'Civil Contingencies Act 2004', Available at:

http://www.legislation.gov.uk/ukpga/2004/36/part/1?view=plain [Accessed February 9, 2011].

HMSO 1980 'Protect and Survive', Available at: http://www.atomica.co.uk/main.htm [Accessed February 9, 2011].

Lakoff, A. 2007 'Preparing for the Next Emergency', Public Culture 19(2): p.247.

Lakoff, A. and Collier, S.J. 2010 'Infrastructure and Event: The Political Technology of Preparedness' in B. Braun and S. Whatmore (eds) Political Matter: Technoscience, Democracy, and Public Life, Minneapolis: University of Minnesota Press.

Lavanya, M. 2011 'School Still in Cyclone Shelter', The Hindu. Available at: http://www.thehindu.com/news/cities/chennai/article2745133.ece [Accessed October 1, 2012].

Lechat, M.F. 1990 'The International Decade for Natural Disaster Reduction: Background and Objectives', Disasters 14(1): p.1-6.

Marres, N. and Lezaun, J. 2011 'Materials and Devices of the Public: An Introduction', Economy and Society 40(4): p.489-509.

McKerrow, B. 2010 'You smell like a fish and drink like one too !', Bob McKerrow Wayfarer Mountains, travel, humanitarian work and opinion. Available at: http://bobmckerrow.blogspot.co.uk/2010/04/you-smell-like-fish-and-drink-like-one.html. Meier, M. 2007 Von der Konzeption 71 zum Zivilschutz 95. Der Schweizer Zivilschutz zwischen Sein und Schein. Lizentiatsarbeit. Freiburg $(\mathrm{CH})$.

Meier, Y. 2007 Die gesellschaftliche und institutionelle Verankerung des schweizerischen Zivilschutzes in den 1950er und 1960er Jahren. Der Zivilschutz als Ausdruck des ambivalenten schweizerischen Selbstverständnisses im Kalten Krieg. Lizentiatsarbeit. Universität Freiburg.

Ministry of Home Affairs 2005 'Design Recommendations for Construction of Cyclone Shelters. National Cyclone Risk Mitigation Project.',

NDMA 2008 Management of Cyclones. National Disaster Management Guidelines., New Delhi: Government of India.

Ormerod, R.N. 1983 Nuclear Shelters: A Guide to Design, London: Architectural Press. Oudshoorn, N. and Pinch, T.J. (eds) 2003 How Users Matter: The Co-Construction of Users and Technologies, Cambridge Mass.: MIT Press. 
Putzier, K. 2011 'Warum die Schweizer so gerne Bunker bauen', Available at: http://www.morgenpost.de/politik/ausland/article1699108/Warum-die-Schweizer-so-gerneBunker-bauen.html [Accessed July 21, 2011].

Rimathé, W. 1969 'Glaubwürdigkeit der Aufklärung beim Zivilschutz', Schutz und Wehr 35(5/6): p.42-44.

Schweizerischer Bundesrat 2010 Bericht des Bundesrates an die Bundesversammlung über die Sicherheitspolitik der Schweiz, Available at:

http://www.vbs.admin.ch/internet/vbs/de/home/documentation/bases/sicherheit.parsys.9457.d ownloadList.86387.DownloadFile.tmp/sipolbd.pdf [Accessed August 22, 2011].

Schweizerischer Bundesrat 1979 Zwischenbericht der Sicherheitspolitik,

Slaton, A.E. 2001 Reinforced Concrete and the Modernization of American Building, 19001930, Baltimore: Johns Hopkins University Press.

Smith, M. 2010 'Architects of Armageddon: The Home Office Scientific Advisers' Branch and Civil Defence in Britain, 1945-68', The British Journal for the History of Science 43(02): p.149-180.

Stafford, J. 2011 '"Stay at Home": The Politics of Nuclear Civil Defence, 1968-83', Twentieth Century British History. Available at:

http://tcbh.oxfordjournals.org/content/early/2011/09/23/tcbh.hwr034.abstract [Accessed February 15, 2012].

Timmermans, S. and Epstein, S. 2010 'A World of Standards but Not a Standard World: Toward a Sociology of Standards and Standardization', Annual Review of Sociology 36: p.6989. 